Boise State University

ScholarWorks

Political Science Faculty Publications and

Presentations

Department of Political Science

5-1-2018

\title{
The Influence of Regional Power Distributions on Interdependence
}

Michael A. Allen

Boise State University 
This is an author-produced, peer-reviewed version of this article. The final, definitive version of this document can be found online at the Journal of Conflict Resolution, published by SAGE. Copyright restrictions may apply. doi: 10.1177/0022002716669809

\title{
The Influence of Regional Power Distributions on Interdependence
}

\author{
Michael A. Allen* \\ Boise State University \\ michaelaallen@boisestate.edu
}

June 6, 2016

\begin{abstract}
Political economy debates about the influence of power configurations in expanding and maintaining global liberalization ebb and flow with the wax and wane of the concentration of power in the international system. The manuscript engages the debate in a novel way from previous scholarship. Employing a series of econometric models that account for regional power, I argue that the global power concentration is ill fit to be the primary predictor of trade liberalization, but instead, regional power fluctuations can dampen and enhance global trends. By incorporating sub-systemic power configurations, we gain a better understanding of the regional variation in states buying into or cashing out of interdependence.
\end{abstract}

*I presented earlier iterations of this paper at ISA 2007, MPSA 2014, and WPSA 2015. I would like to thank Benjamin Fordham, David Clark, Michael McDonald, Julie VanDusky-Allen, Olga Shvetsova, Mark Souva, Michael Flynn, and Tobias Hofmann for their feedback. All supplementary materials, including data, the appendix, and Stata replication files, are available at: www.ma-allen.com. 
This is an author-produced, peer-reviewed version of this article. The final, definitive version of this document can be found online at the Journal of Conflict Resolution, published by SAGE. Copyright restrictions may apply. doi: 10.1177/0022002716669809

\section{Introduction}

Research on the link between power dominance and trade liberalization appears to ebb and flow with the flow and ebb of global power concentration. While we observe liberalization during the 19th century under British hegemony and during the latter half of the 20th century as American power increased (Kindleberger 1973), scholars questioned the viability of sustained liberalization as American power seemed to evaporate in the 1970s. This series of debates thinned by the 1990s as the American moment manifested and rapid changes in international institutions, political regimes, and economic policy produced rapid globalization that seemed unthinkable in the previous two decades. While there have been some research programs that continue to evaluate how the various types of hierarchy affect global patterns of trade (e.g. Lake 2009), there is much about this relationship that remains unexplored.

This study explores how research has ignored the effect of countervailing forces at a lower level of analysis: the region. I argue that, while there are global trends in trade that correlate with the rise and decline of global power concentration, regional power configurations enhance and diminish those effects. When there is relative power parity regionally, then the effects of systemic pressures for liberalization are prominent as there does not exist a strong regional force to counteract a global power. However, if a regional power is dominant over its peers, then it is freer to act against globalizing trends due to the absence of a significant rival. Consequently, while asymmetric global systems seem to produce periods of liberalization, regions of asymmetry work to act against those trends; the most conducive power configurations for trade liberalization requires an asymmetric global power with regions of middle powers that rest at parity.

To ascertain evidence for this relationship between regional and global power configurations on trade, I analyze three different units: directed dyad-years, undirected dyad-years, and country-years. Examining both import activity as well as total trade, I find that two dis- 
tinct measurements of regional power disparity correlate with decreased trade activity while parity encourages trade activity. States in neighborhoods dominated by a single regional power tend to have weaker trade activity than states in multipolar neighborhoods.

\section{Power and Interdependence}

The treatment of power and hierarchy in this research follows previous scholarship in conceptualizing power as both the ability to use various assets to influence actors to behave differently than they otherwise would have as well as the ability to achieve desired outcomes despite resistance (Krasner 1976; Gilpin 1983). This ability, whether latent or manifest, gives states the capability to influence the rules and institutions that constrain and enable other actors' behavior. Waltz argues that the rank of states comes down to "size of population and territory, resource endowment, economic capability, military strength, political stability, and competence." (1979, 131) The effectiveness of power can change based on the configuration of the international system or with the emergence and obsolescence of the technologies that drive the reach and applicability of exercising power (e.g. military technology, communication speed, transportation costs). For some theories, this project included, the arrangement of states and their relative power can both condition the environment that they interact in as well as change their own effectiveness in international affairs.

Scholarship on international hierarchy, power, and trade is a fundamental component of international relations scholarship and transcends political science and political economy as scholars in related fields such as history (Gallagher and Robinson 1953), economics (Yarbrough and Yarbrough 1987), and sociology (Chase-Dunn, Kawano and Brewer 2000; Wallerstein 2000) research these relationships. While early, dominant strains of realism dis-

missed the intersection between politics and economics as merely "low politics" (e.g. Waltz 1979), other scholars, notably Hirschman (1945), pursued the bidirectional influence of na- 
tional power and foreign trade (Barbieri 1996).

The research program of hegemonic stability theory establishes a wealth of research between structural and national power with liberalization and conflict in the 1970s. With the decline of US power seemingly evidenced by the US failure to achieve its objectives in Vietnam, petroleum exporters establishing an oil embargo, and the collapse of the Bretton-Woods system, it was apparent that the force that kept global financial and economic institutions afloat was unlikely to persist. Kindleberger (1973) saw the present crisis and the early 1930s as linked to the failure of those capable of exerting leadership being unwilling to do so. Specifically, the United States had the potential to prevent economic retrenchment and, due to domestic pressures, did not don the mantle of global leadership. Krasner (1976) offered a structural version of hierarchy and found evidence for a causal relationship between periods of global hegemony and global trade activity; scholars replicated this result with varying definitions of hegemony, hierarchy, and structural power concentration (Mansfield 1993; Lake 2009).

The distinction between leadership and structural theories of power and trade led to an explosion of literature over the next decade. In the structural study of global power concentration, part of the debate concerned establishing the conditions for when a power would pursue liberalization. A persistent issue in international trade are states that erect barriers to imports to preserve some domestic industry (Midford 1993). Tariffs are domestically inefficient and hurt both domestic consumers, domestic producers, as well as trading partners (Tullock 1967; Frankel, Romer et al. 1999). Early research posited that global liberalization was a public good that creates a basic collective action problem; only when a single powerful state emerges that there is an actor with enough incentive to overpay for the good and solve the problem (Krasner 1976; Gowa 1989). The issue of whether liberalized international trade was actually a public good or an excludable private good persisted (Conybeare 1984; Snidal 1985), but ultimately does not matter for advancing our understanding here. 
A dominant state that excels in financial, economic, and military power has a distinct interest in establishing an economically interdependent world by encouraging states to reduce barriers to trade. In the short term, a dominant power will benefit from encouraging other states to drop their protectionist policies and open their markets to global trade. Given that the dominant state is an economic power, the state has a distinct interest in having access to raw materials, finished goods, and markets in which to sell its products. In the long term, as states become more dependent upon the established economic and political order, they will have less incentive to seek to change or overthrow the status quo (Organski 1958; Organski and Kugler 1980). The primacy of a state affords it the ability to use its position, hard power, and soft power as tools to bring recalcitrant states to a similar perspective as its own. This alignment of interests between a dominant power and an emerging power may explain why the United States and Great Britain do not go to war despite the US emergence as a major power by the end of the 1890s that quickly surmounts Britain in latent power. The United States is resistant to two major economic policies Great Britain promotes in the latter-half of the 19th century, trade liberalization and adoption of the gold standard, but becomes a champion for both policies as it becomes a global power at the end of World War II. The effect of this shifting of potential rivals' interests on trade is to make it such that a future decline of the dominant state does not undermine the institutions it created (Keohane 2005). That is, the would-be rival, while jockeying for primacy, will have incentives to maintain the systemic rules (and accompany institutions) of the declining power.

The pursuit of liberalization is not globally absolute or temporally linear. Instead, the liberalization process for the dominant state will require it to spend resources convincing resistant states to adopt the norms it promotes. Some countries will be more prone to adopt increasing levels of liberalization while others will have domestic and regional reasons to resist the evolving norm. As the dominant state uses a variety of instruments to compel states to liberalize, we will see a range of early to late adopters. Likewise, the dominant 
state may go through periods where it more or less aggressively pushes its agenda based on competitive demands for its resources.

Great Britain during the 19th century becomes the globally dominant state after the end of the Napoleonic Wars; however, it is slow to pursue liberalization and makes its greatest leap when it repeals the Corn Laws in 1846. It pushes for liberalization and global adoption of the gold standard as part of its foreign policy, but not all states follow (Gallagher and Robinson 1953; Scherrer 1995). The United States, the state later to assume Great Britain's global mantle, does not formally adopt the gold standard until 1903 and does not adopt unconditional Most Favored Nation Status as a trade instrument until 1922, well after the decline of 19th century's unipolar system. The United States' increasing status as a global exporter encourages a domestic political realignment around trade that allows the passage of the Reciprocal Trade Agreement Act of 1934 (Bailey, Goldstein and Weingast 1997; Hiscox 1999). The post-World War II configuration allows the US to have a central hand in creating the institutions of the contemporary global financial and economic system including the World Bank, the International Monetary Fund, and the General Agreement on Tariffs and Trade (GATT). While this sets the stage for the promotion of liberalization during the Cold War, the US pursues a variety of agreements globally through various rounds of GATT/World Trade Organization meetings and regionally through agreements such as the North American Free Trade Agreement, the Central American Free Trade Agreement, and working with regional organizations such as the Association of Southeast Asian Nations. The relationship between more hierarchical structures and liberalization is not automatic, but an evolving process.

The literature on the relationship between power, hierarchy, and liberalization, abated to a significant degree after the collapse of the Soviet Union; the shift to multipolarity that seemed apparent in the 1970s and 1980s became an unlikely prospect in the near future. Scholars saw the bipolar system of the Cold War transitioning to multipolarity as emerging 
economic powers (Japan and Germany), rising regional economic blocs (Europe and OPEC), and new centers of power (China and India) threatened to become great powers (Keohane 2005). The dissolution of the Soviet Union catapulted the United States to unrivaled unipolarity and the emerging threats from the previous decades were unable to catchup. However, the research, as well as debate, still offers active scholarship. Most prominently, Lake's (2009) recent research on hierarchy looks at the provision of security as a series of contractual bargains between the United States and other actors. Other states trade away portions of their sovereignty in exchange for security guarantees and military resources. This series of contractual relationships is the cornerstone in which the US maintains hierarchy.

\section{Regions of Prosperity}

A globally dominant state seeks to integrate economies by inducing trade liberalization as long as the costs of providing incentives are less than the expected benefits derived from that system. Despite a desire to pressure all states to globalize, a world power cannot solely enforce global norms as its own power is inevitably limited and costs of enforcing regimes become exponentially large (increasing by the number of potentially defecting states and monitoring any pair of states). Like any other actor, it faces opportunity costs in pursuing effective liberalization. If the global power attempted to curtail all defection from international regimes, it would invariably overstretch itself - in terms of capabilities of providing rewards and punishments in using military, economic, and diplomatic tools - and create the conditions that encourage retrenchment instead of liberalization (Alt, Calvert and Humes 1988).

A dominant state, seeking opportunities that allow it to achieve its objective of increased liberalization, will look for regional configurations that are the least costly in achieving its preferences. Within any given region, we see a replication of global polarity configurations as 
issues of power parity define regions where two or more actors have similar power statures, or disparity where no other state rivals a prominent single state in power. In a region of asymmetric power distribution, there is only one actor that can act as a possible agent to promote liberalization. This constrains liberalization promotion as an unchecked regional power does not have other regional threats to prevent it from renegotiating the regional status quo. Consequently, even if a regional power has similar preferences for liberalization as a global power, it still affords it more opportunities to defect on maintaining such regimes (Alt, Calvert and Humes 1988). To invoke the principal-agent dilemma that mirrors the liberalization dilemma, the actors employed by a principal are not always faithful to the principal and the risk of agency loss remains (Ross 1973).

A regional power has a continuum of trade policies it can pursue from autarky to complete liberalization and its position affords it the ability to promote a similar policy regionally. A rational power may find it beneficial to pursue either an optimal tariff policy or a regional trade bloc. The former policy would seek to enrich itself (protecting its industries while encouraging other regional actors to open their markets) (Brander and Spencer 1992; Gowa 1989); the latter policy results in trade diversion where regional states replace their global trading partners with regional ones (Bhagwati and Panagariya 1999; Freinkman, Polyakov and Revenco 2004). Both arrangements, from a global perspective, lead to suboptimal trading patterns and lower levels of trade, but are uniquely advantageous relative to a globally liberalized marketplace. Regional powers can protect their markets or regions from competition while taking advantage of other states' liberalized markets.

Using metrics I describe in the research design section, an example of such a configuration are the Caucasus countries of Georgia, Armenia, and Azerbaijan. Each country has a relative region dominated by Russia in the post-Cold War period from 1991 through 2007. In 1994, the Commonwealth of Independent States (CIS) agreed to create a free trade area, but failed to ratify a treaty to actually do so. Throughout the 1990s and the 2000s, Russia 
pushed for regional trade deals while attempting to dissuade the three states from accepting stronger institutional agreements with the West, particularly the European Union and the North Atlantic Treaty Organization (Nygren 2007). Consequently, while lowering trade barriers would increase trade activity among members party to a preferential trade region, the creation of a limited regional trade agreement would result in trade diversion. As the countries pursued various policies both in favor of Russia and the West, Russia attempted to limit the Caucasus' movement to the West both politically and economically (Babayan 2015). For example, Russian-Georgian diplomatic relations break down, Russia imposes energy, trade, and migrant sanctions on Georgia, and goes to war with Georgia in 2008 (Newnham 2015). Georgia withdraws from the CIS entirely. Armenia initially seeks economic cooperation with the EU, but rejects an Association Agreement in 2013 and instead joins the Russian supportive alternatives of the CIS Free Trade Area in 2011 and the Eurasian Customs Union in 2014.

Alternative to an asymmetric region, a regional power is less capable of achieving an optimal tariff or a regional trade bloc if they have a competing power capable of demanding reciprocal reductions in trade barriers. The regional rival, by invoking global norms and acting on behalf of the globally dominant power, can both constrain the anti-liberalizing power, encourage the anti-liberalizing power to become enmeshed in the liberalizing statusquo, and advantage itself by aligning with the global power. In regions with competing powers, both states may find it advantageous to be on the side of the global power than developing both a regional and global antagonist. By having two or more potent rivals in a region, such power parity, regardless of whether the states are friends or foes, act as a check on the behaviors of states attempting to renegotiate the status quo. A regional peer becomes a monitoring mechanism as the monitoring state has an incentive to encourage norm compliance.

The globally dominant state prefers to deputize agents instead of being the sole, global 
sheriff as norm enforcement and maintenance are increasingly costly; if a global power can defer costs to agents that are willing to bear the burden of monitoring and enforcement, then the global power will prefer to put liberalization pressure on regions that offer the best costbenefit calculation. In addition to coercion towards a recalcitrant minor power, the global power can credibly commit to working and rewarding the monitoring state over the defecting state, shifting the balance of power within a region. Alternatively to the asymmetric region, regions at parity have at least two states that engage in rule-making and norm-setting within their region and liberalizing states can hold their markets hostage if a rival state is resistant; regional powers can demand reciprocation for access to their own markets. This demand, and the norm of trade reciprocity, facilitates further liberalization.

The competition between power-equivalent states combined with the tools of an effective regime, which a globally-dominant power underwrites, create the conditions to make these regions more prone to liberalization than regions without power parity. With each regional power keeping each other in check under global regimes, this creates a ripple effect throughout the region in two ways. First, it establishes the norm of trading practices within the region between the regional powers and lesser powers within the region. Rivalrous powers will seek reciprocal reductions in trade barriers with smaller countries in the region to maintain their relative power (otherwise the trading relationship would be asymmetric). Additionally, given the implications of gravity models of trade and the known correlation between economy size and power, the regional powers are the regional trading centers for any given area and increased liberalization of their economies will allow actors more opportunities to import and export with these powers.

Post-War Europe exhibits this behavior quite well as, while the US began to push for greater institutional mechanisms for liberalization globally, the balance of power between European rivals increased. France, in particular, exemplifies this pattern where this study's measure of bilateral dominance and regional dominance for France changes dramatically 
between 1929 and 1945. France's region became dominated in 1939, but drops dramatically as Europe shifts to the post-war era. As regional parity drops below a standard deviation of the global mean, we see France become one of the six founders of the European Coal and Steel Community, help establish the European Common Market, and help create the groundwork for the European Union. This is in concert with former rival Germany as both countries seek to bind each other both within the region and to the increasing liberalized global economic order (Dinan 2004; Gillingham 2004).

In sum, in regional disparity, a state that challenges the status quo may or may not catch the attention of a global power. However, in regional parity, there are more checks upon actors that attempt to undermine international regimes. These checks increase the likelihood for defection to be detected and facilitates norm compliance with liberalization. The role of regional configurations affords the following hypothesis:

Hypothesis 1. Countries in a region with a dominant regional power will trade less than countries in regions that have two or more powers at parity.

We should expect both regional and global pressures for trade liberalization in regions of power parity. States, unable to cheaply defect on liberalization norms, will either reduce existing barriers or, at a minimum, not erect additional barriers to trade. Reductions in barriers and maintenance of existing trade liberalization policies make the opportunities for trade more lucrative and we should see a corresponding behavioral response to a reduction in those barriers: non-state actors will engage in more trade.

[Figure 1 here]

Given the differing predictions, figure 1 provides a break down as to the relationship between global power configurations and regional power configurations. The primary argument advanced in this paper focuses on the left hand side of the table where scholars posit 
that trade promotion ought to happen. When there is regional dominance, we expect the promotion of trade to be countered by regional recalcitrance; when there is parity, states will use the norms of liberalization to prevent their rivals from free-riding and benefiting themselves regionally. Under conditions of global bi- or multi-polarity, the regional configuration matters less as liberalization promotion is not the norm. Regionally dominant states may still attempt to form regional trade blocs or grow their power through protectionism while regional states at parity have no norm to use against each other. It is still possible for a small number of states to seek liberalization as a way to encourage mutually beneficial trade (Krasner 1976), but that cooperation is less likely without the global power's shadow over the region.

\subsection{Defining Regions}

Trying to conceptualize what to include within and without a region is a difficult enterprise. Classic attempts, such as those that employ the Correlates of War database, may define regions purely as a state's location with a defined geographic area such as Europe, Africa, and Asia. The problems of this approach are twofold. First, it often removes cross-cutting influences from just outside of the region that have meaningful implications for a country's decision-making. Enough countries live on the borders of these regions and to exclusively define countries like Turkey, Egypt, Russia, or Morocco as existing in a single region would miss important influences on their behavior. Second, classical regions are limited in conceptualizing influence as they often include countries that are unlikely to interact in a way to consider each other's power. Mongolia is in the same region as Indonesia, but their influence on each other is historically minimal.

Scholars have attempted to address these pitfalls in various ways. Russett (1967) uses different techniques to create regions based on social and cultural homogeneity, political attitudes, political interdependence, and economic interdependence, establishing different 
behavioral definitions of regions. Lemke (2002), in examining how power transition theory may work at the regional level, use power degradation and distance to figure out which countries can meaningfully deploy troops in each others' territory. This study examines regions as neighborhoods. For each state, I consider its region to include all surrounding states the referent state shares a border with. While this is a restrictive assumption, it does satisfy the condition of being politically relevant as neighbors are the most likely to go to war (Bremer 1992). Consequently, this construction of regions facilitates studying if a state's immediate neighborhood power-configuration influences a state's economic behavior.

\section{Research Design}

Constructing an appropriate test of how trade fluctuates based on exogenous factors is not always a straightforward task as there are numerous ways in which scholars conceptualize models of trade. To conduct a broad series of tests, I use three different units of analysis to examine how regional disparity affects trade. For the first series of estimations, I use directed-dyad-years. This data structure facilitates examining how states restrict or loosen their import barriers within any pair of state. ${ }^{1}$ Starting with imports is appropriate as states are generally willing to export to other countries and, while they are more likely to guard their domestic industries; trade protectionism typically focuses on protecting importsensitive industries.

The second unit of analysis is the undirected-dyad-year where every pair of states in a given year is an observation. This data frame enables me to evaluate whether regional parity affects the total trade between two pairs of states. Traditionally, theories of power structure and trade focus on imports as the state promoting liberalization does so by encouraging states to reduce their trade barriers (i.e. tariffs and quotas); however, the effects of power

\footnotetext{
${ }^{1}$ Technically, since it is directional dyads, a test of imports is also a test of exports since all flows from country $i$ to country $j$ are the inverse of flows from country $j$ to country $i$.
} 
concentration should put pressure to reduce trade barriers in both countries, resulting in changes in both imports and exports. Consequently, if both countries are reducing trade barriers, trade should increase in regions of parity. Given that the undirected nature of the dyads, any country-specific variable from directed-dyads will require generalization to typify the dyad as a whole. For all such cases, I take the maximum value of a variable to examine the effect of strong disparity or regional dominance. Since our expectation is that the larger powers and economies make trade more likely between states, then it will be the larger economy that drives the relationship within the dyad. In keeping in line with the gravity model of trade, I sum the populations for both states; this aggregates the size of the collective market of the two states.

The third set of estimations use the country-year level of analysis. Divorcing the data from dyads allows a third test as to whether regional power structures systematically influence a country to trade less with all countries. The monadic version of the data can eliminate some level of pair-wise bias that may occur due to non-modeled variables that systematically increase or decrease bilateral trade. This set of data represents the broadest test of the theory as it eliminates controls available in dyadic estimates.

In all estimations, I employ linear regression to estimate either the natural log of imports or total trade. For the directed- and undirected-dyadic models, I use a lagged dependent variable to estimate trade in the observed year. All models employ clustered standard errors using the appropriate unit of analysis, use dyadic or monadic fixed effects, and use a series of 4-knot, restricted cubic splines to account for temporal trends.

\subsection{Dependent Variables}

To test the theory, I employ the Correlates of War (COW) data on international trade (version 3.0) (Barbieri, Keshk and Pollins 2009). These data afford an unparalleled look at cross-temporal trends as it contains data on bilateral trade flows from 1870-2009. This longer 
This is an author-produced, peer-reviewed version of this article. The final, definitive version of this document can be found online at the Journal of Conflict Resolution, published by SAGE. Copyright restrictions may apply. doi: 10.1177/0022002716669809

look at historical trading is atypical in the trade literature due to the missingness of much cross-spatial economic data prior to World War II. However, given the temporal range of the data, I must make some compromises in estimating this series of trade data. Notably, states did not calculate their Gross Domestic Product (GDP) prior to World War II and GDP is a fundamental component to estimating trade (Isard 1954). Thus, I use GDP substitutes when employing the COW trade data. ${ }^{2}$ Barbieri, Keshk and Pollins (2009) measure the trade data in current millions of US dollars. Since the data extends back to 1870, using the Consumer Price Index (CPI) deflator is difficult as the US Bureau of Labor Statistics only covers the 20th century (Sahr 2004). As such, I employ Sahr's (2003) estimated CPI value for the full range fo the data. After adjusting for CPI, I added one to all true-zero values and logged the final value. ${ }^{3}$

\subsection{Regional Power}

To include the role of regional power in predicting trade, I construct two different variables to account for regional power considerations as isolated processes from global power configurations. To accomplish this, I start by using the COW Direct Contiguity data (version 3.1); I determine any given state's region by using the most relaxed assumption of contiguity (two states share a border or are within 400 miles of each other over water) to develop the observed states set of neighbors. ${ }^{4}$ These shifting regions represent different geographic areas

\footnotetext{
${ }^{2}$ As a robustness check, I estimated the models using Gleditsch's (2002) GDP and trade data set that covers 1950-2000. This more restrictive data is complete for the time period as Gleditsch imputes any gaps in the data. When estimating these models using the log of trade, I substituted the log of GDP for the CINC score for each country. In both sets of models, there remained a negative relationship between disparity/regional dominance and trade activity. Additionally, I used the same variables in Rose (2004) and found similar results. These models are available in the appendix.

${ }^{3}$ Adding a one to the value converts the final value to zero; the natural $\log$ of a zero value is undefined and analysis would treat such cases as missing.

${ }^{4}$ I exclude states without a neighborhood from consideration in the analysis. Constructing an artificial measure of power parity to include such neighborless states would require further assumptions about parity that may not be tenable.
} 
of concern for any given state and allow for a regional power to remain uncontested in some regions while contested in others.

For each state's region, I create two measures. To assess power, I employ the COW data on National Material Capabilities (version 4.0) that indexes six component measures of total population, urban population, electricity consumption, steel/iron production, military spending, and military personnel (Singer, Bremer and Stuckey 1972; Sarkees and Wayman 2010). The total of these six metrics form the Composite Index of National Capability (CINC) which represents a state's share of the world's total of those six indicators. The CINC score is a common proxy measurement for a state's relative power in the international system. The first measure of regional dominance takes the most dominant power $(\mathrm{k})$ in the neighborhood of the observed state and creates a measure of its power relative to the total share of power of the observed state's region $\left(\frac{\text { Power }_{k}}{\text { Power Region }_{\text {R }}}\right)$. The value for regional dominance ranges from 0 to 1 where lower values suggest relative parity within a region and higher values of the proportion represents a state that possess a larger share of all of the power within a region.

Disparity examines the ratio of the most powerful state $(\mathrm{k})$ in the region as compared to the sum of its power and the second most powerful state $(\mathrm{m})$ in the region $\left(\frac{\text { Power }_{k}}{\text { Power }_{k}+\text { Power }_{m}}\right)$. The previous metric may be a function of the number of states within a region and suggest there is parity in a region when there may be one dominant state, but smaller ones that, in sum, rival the regional power's power. This metric examines whether the most powerful state has at least one other regional state that is at or near parity. Since I calculated each measure on the observed state, it informs the model whether the state has at least two credible states that can exert influence over the observed state. To make the variables comparable, I transform the disparity variable to take on values that ranges from 0 to $1 .^{5}$

\footnotetext{
${ }^{5}$ The natural value of disparity ranges from .5 (complete parity) to 1 (complete disparity). The conversion

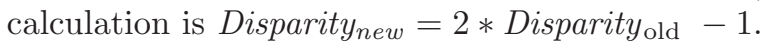


Both measures capture different types of parity and act as tests of the hypothesis.

\subsection{Control Variables}

I include the gravity model of trade as a standard prediction of bilateral trade between two countries (Anderson 1979; Isard 1954; Bergstrand 1985). Generally, trade between two states is a function of population multiplied by GDP divided by distance. Large populations and economies will trade more than smaller ones while the distance between two states raises the costs of trade. However, gravity models do vary over whether population should have a positive effect; some models suggest it is a representation of market size while others argue that it represents a higher likelihood of trading less due to self-sufficiency (MartínezZarzoso and Nowak-Lehmann 2003; Carrere 2006). Taking the log of both sides of the equation, we expect that the natural log of trade positively correlates with $\ln (G D P)$ while negatively correlating with $\ln$ (Distance); though, given previous research, I have ambiguous expectations about the role of population. I use Gleditsch and Ward's (2008) on capitol-tocapitol distance; however, due to the presence of dyadic fixed effects, the distance variables consistently drop out of the estimations as it perfectly correlates with the fixed effects.

As mentioned in the dependent variables, the temporal range of GDP covers the postCold War era. As a proxy for GDP when using the COW trade data, I employ the CINC score of both countries. While this is not a perfect measure of GDP or economic activity, the CINC scores strongly, positively correlate with GDP and scholars have traditionally used both metrics to measure state power and capacity (Kim 2010; Allen and DiGiuseppe 2013). Like with GDP, CINC-scores should positively correlate with trade.

Given that the regional power hypothesis suggestions mediation for the polarity of the global system, it reasonable to include measures to account for that. This is problematic as many theories of power concentration do not speak directly to minor shifts in the power distribution of the system, but treat global dominance as a binary variable: either the globe 
experiences unipolarity or it is not. For the 1870-2001 time period, most measures would be uniform and either include everything but 1914-1945 as unipolar or only include pre-1914. ${ }^{6}$ In both of these cases, these time periods account for less than $2 \%$ of the data each and do not offer substantial temporal variation. I include two different continuous variables that ascertain different components of global power. First, as is common with previous studies looking at trade patterns (Mansfield 1993), I measure the concentration (CON) of power among the major powers in a given year. I calculate system concentration as follows:

$$
C O N=\sqrt{\frac{\sum P_{i}^{2}-\frac{1}{n}}{1-\frac{1}{n}}}
$$

Where $P$ is the CINC scores of the major powers in a given year and $n$ is the number of major powers for that year (Singer and Small 1972; Ray and Singer 1973). Higher concentration values indicate that a smaller proportion of major powers hold a larger percentage of relative power for the observed year while lower values indicate a more uniform distribution of power among major powers. This variable measures the change of power at the system-defining level of majors powers, but given that I expect the effect of regional power configurations to heighten and dampen global trends, it is natural to assume there is interaction between the systemic and regional processes. To attempt to account of this, I allow for an interaction between concentration and regional power metrics. As I discuss above, the majority of the cases occur in a period of active liberalization and, given the temporal range of the data, the interaction is inherent to the model. However, I also offer a final check of this concept using the different subsamples of hierarchy to assess the performance of regional variables in context of global periods.

In addition to concentration, I include the CINC score for the United States $\left(C I N C_{U S}\right)$

\footnotetext{
${ }^{6}$ While the Cold War period is clearly bipolar, hierarchy scholars see the post-World War II period as hegemonic expansion with the establishment of trade institutions and the promotion of liberalization. There is some debate over whether the US is in hegemonic decline in the 1970s and Mansfield (1993) visits these debates by creating binary variables for hegemonic periods.
} 
as a means to measure the fluctuation in the United States' relative power with the rest of the world. Since the US CINC score is a component of the concentration value, this variable will act as a secondary, modifying variable to the overall effect of global concentration.

A final control is international conflict as derived from the COW interstate war data (Sarkees and Wayman 2010). The state of the discipline suggests that there is a recursive relationship between trade and conflict as they are mutually causal; theoretical arguments suggest that both trade should effect conflict (Russett and Oneal 2001) and that conflict should cause disruptions in trade (Keshk, Pollins and Reuveny 2004). Given the evidence that conflict does decrease activity, I expect that a state at war is less likely to trade. Consequently I include a binary variable for whether either state in the dyad is at War or, in the monadic data, if the observed state at war during that year; in the dyadic data, either country experiencing a war will be less capable to trade with its partner even if that partner is not at war.

\section{$5 \quad$ Results}

[Table 1 here]

Table 1 offers the initial results with directed-dyad years as the unit of analysis. ${ }^{7}$ Since the nature of the trade regime and theories of economic hierarchy concern how actors can encourage other states to reduce trade-barriers, examining the role of imports provides information as to whether we see a behavioral adjustment to a change in policy. Given that the unit of analysis contains directed-dyads, having information about both actors in the dyad is important. Consequently, country-specific variables contain one value for each member of the dyad.

\footnotetext{
${ }^{7}$ I have suppressed the results of the splines.
} 
The first model presents the basic estimation without the independent variables of interest. Across the majority of coefficients, these variables have the expected relationship with imports. CINC scores positively correlate with trade for both states; previous imports positively predict imports in the observed period. The log of population is negative which is in line with previous gravity models that account for GDP as it proxies the resistance larger countries have to trade (absorption effect). The concentration of the power in the system and war both negatively correlate with trade in each dyad. The only control variable that is inconsistent with prior expectations is the United States CINC score. As mentioned in the research design, this value is a pseudo-interaction term as the CON value contains information about the United States' score for the majority of the study's time period and acts as a conditional effect upon the magnitude of the CON value. Additionally, the variable may be capturing intra-period trends. $98 \%$ of the sample in Table 1 is from periods of global liberalization (typically, a binary variable in past studies), and the continuous measure of the United States' CINC score may be capturing other processes.

The two independent variables of interest produce results consistent with the hypothesis. The disparity variables (model 2) measuring the difference between the two most powerful states within a region is negative for both countries suggesting that, as disparity increases, the trade flows in the relationship decrease. This implicitly means that higher levels of regional power dominance has a negative effect on exports; if the premise of the paper is correct, the higher level of regional asymmetry for $\operatorname{state}_{B}$ produces a region of permissive protectionism. This leads to a more limited trading space both with the observed state's neighbors and its other potential trading partners - that is, the norm of liberalization reciprocity would freeze a protectionist state's ability to trade in general and regional trade agreements are even less likely. The regional dominance variables in model 4 also produce results consistent with the hypothesis: As a state becomes more dominant in a region relative to all other states in that region, the amount of trade activity by other states in that region decreases. 
For model 4, the mean for the lagged dependent variable is 1.23 and a $1 \%$ change in the lagged dependent variable accounts for a $0.77 \%$ change in the estimated dependent variable in table 1 . Consequently, the remaining variables are functionally capturing how they may affect the year-to-year changes in imports while also taking into account the dyadic fixed effects. Overall, this is a small amount of variance not captured by the fixed effects or the lagged trade value. In the case of disparity, a change from a competitive region to a dominant region would account for a $10.52 \%$ decrease in the dependent variable. While significant, this is potentially underwhelming when compared to the other variables that predict trade activity. This diminished result is likely a function of the larger sample accounting for 130 years of data with variable global trading patterns. Additionally, given the directed-dyadic nature, a stronger effect may be present, but limited as the coefficient accounts for the mean change in the dependent variable over nearly a million different observations. Thus, capturing a $10 \%$ change in trade is substantial. Given the initial results of both regional dominance and disparity, the results are promising.

[Figure 2 here]

Models 3 and 5 introduce the interaction terms for their counter-parts in models 2 and 4. The interaction terms determine if the regional power concentration variables are acting in concert with the systemic changes happening with major powers. Brambor, Clark and Golder (2006) illustrate that interpreting the significance of an interaction directly from the regression standard error is misleading and, to understand the significance of the interaction, requires combining the coefficients and the standard errors of both the interactive and constituent terms. Figure 2 graphs the results for both models 3 and 5 . Model 3, charts a and $b$, show the marginal effects of disparity and concentration on the dependent variable. For part a, the variable is statistically different from zero throughout the model, suggesting a negative result from the interaction, but the effect does not vary across the range of con- 
centration. The marginal effect of concentration tells a similar story in figure $2 \mathrm{~b}$ where the interaction is significant, but does not show variation across its range. Consequently, there is not a meaningful interaction between these variables.

Model 5 tells a more stark story in regards to the joint relationship between regional dominance and concentration. The marginal effect of regional dominance does not significantly vary across the range of concentration in figure 2c. In figure 2d, the marginal effect of concentration is indistinguishable from zero up until $28.90 \%$. After that, it is negative and significant. Consequently, for areas that are asymmetric, concentration appears to have increasingly suppressive effects on trade giving some support to our expectations on the role of regional dominance relative to global power concentration.

[Table 2 here]

The estimations of table 2 ask a different question than the previous two tables as it uses undirected dyads. Given this formulation, instead of asking how regional power asymmetry affects imports, we evaluate how regional disparity and dominance impact total trade. Given that country-specific variables not meaningful in undirected analysis, I use the maximum value of each of the country-specific variables as a gravity effect on the dyad. Therefore, the variables here look at the pair of countries from the perspective of the country that is the strongest $(C I N C)$, the sum of the state's population $(\ln (p o p))$, and has the most dominant region. Thus, lower values on dominance means that both states are at a particular value for dominance or lower. As with table 1, our control variables are consistent in the model 1.

[Figure 3 here]

The regional power concentration variable in the second estimation provides a negative relationship between disparity and trade. If either state within a dyad belongs to a region of increasing dominance, it will exhibit a depressant effect upon the trade in that relationship. 
Model 4 suggests that regional dominance has a similar effect within the dyad. Figure 3 provides the marginal effects of each variable of interest. In figure $3 \mathrm{a}$ and $3 \mathrm{c}$, the effects of disparity and regional dominance do not vary for different levels of concentration, but is static; $2 \mathrm{~b}$ also exhibits this behavior for the marginal effect of concentration relative to disparity. Figures $3 \mathrm{a}$ and $2 \mathrm{~b}$ imply that there is not a meaningful interaction between concentration and disparity in model 3. Strikingly, figure 3d demonstrates concentration having increasingly negative marginal effects on trade. Unlike figure $2 \mathrm{~d}$, we also see concentration positively affecting trade in regions of parity. Thus, we are most likely to see concentration positively affecting trade in regions with two or more competing states, but the opposite effect for areas that contain a single regional power. This may explain the divergence in findings for the relationship between concentration and liberalization.

[Table 3 here]

Table 3 presents the third unit of analysis: the country year. By eliminating the bilateral trading partners for each country, these estimations examine how being in a region of disparity affects a country's aggregate trade levels. For the full sample, the disparity measure offers a $22.55 \%$ reduction in trade while regional dominance predicts a $50.69 \%$ decline. While there is a more than $100 \%$ increase in the magnitudes of the variables than in the previous models; this is not surprising for two distinct reasons. First, the sample space is smaller than the directed dyadic sample by an order of magnitude and the independent variables may be capturing more information that we are not observing in the monadic unit of analysis. The monadic unit of analysis collapses the nuances of bilateral interactions into a single aggregate that ignores the makeup of actual and potential trading partners. Second, more promisingly, these models capture all trade done by a state within a region and ignores trade partners. It directly asks whether a state within a region of disparity has suppressed trade activity compared to a state within regional parity. Overwhelmingly, states in asymmetric regions 
face a 20\%-50\% decline in trade when compared to similar states in regions of parity.

[Figure 4 here]

Figure 4 compares four different models in showing the effect of disparity and regional dominance on trade activity. In all four figures, I hold all the variables, except the independent variables of interest, at their respective means or modes. Figure 4 a employs model 2 in table 1 and shows the reduction in imports across the range of the disparity variable. Figures $4 \mathrm{~b}$ and $4 \mathrm{c}$ employ regional dominance without and with the interaction term respectively. Instead of examining imports as the dependent variable, it examines total trade within an undirected dyad. As such, the total trade variable is larger than in figure 3a and the magnitude of the decline is also larger. Generally, when controlling for the interactive possibility between models 4 and 5 in table 2, the result on trade is roughly the same. Figure 4 d shows a different effect than the previous three figures as it examines the monadic relationship between regional dominance and trade. The dependent variable mean and median are much larger, and as noted in the estimates for table 3, the decline is more substantial than the previous figures.

\subsection{Does Global Hierarchy Matter?}

The previous results provide evidence for the relationship between various regions and the concentration of the international system; however, most of the earlier theories of hierarchy and hegemony see the international system as a binary event where either global hierarchy exists or it does not. Using the classification of hegemony by Gilpin (1983) as tested by Mansfield (1993), I break the sample into three periods: British hegemony from 1871-1914, inter-war non-hegemony from 1915-1944, and post-War US hegemony of 1945-2007. For each period, I use model 2 and 4 from Table 1 to examine the relative effect of regions in each time period and I exclude the appropriate hegemonic state in the pre-War and post-War periods. 
Additionally, I exclude the interactive term as, if the previous scholarship is correct about international dominance being a binary condition, then the regional variables are inherently interactive. $^{8}$

\section{[Table 4 here]}

First, as noted previously, the sample sizes are drastically asymmetric. Notably, the first two periods account for just over $3 \%$ of the data, meaning that most of the data exist in the post-War time period. This is a result of a data collection bias that favors the present as well as fewer possible dyads in these time periods. The 1871-1914 time period exhibits coefficients in the expected direction for model 1 and 2, but fail to achieve statistic significance. This likely results from one of two considerations: First, this could be from taking a thin slice of the sample to estimate or, second, this period is marked as a period of British decline and countervailing states/rises could lead to higher variance in the results. The second time period provides inconsistent results where state A, in an asymmetric region, imports less, but if its trading partner is in an asymmetric region, it imports more while state B exports more. The effect, in both model three and four, is strongest for the importing state; if two states have identical regions, they will trade less on average. This inconsistency, regions having mixed results, follows from the lack of international hierarchy in the time period; without the global push for liberalization, regional powers can still isolate their region when unchallenged. Finally, the post-War period (models 5 and 6) behaves as expected where asymmetric regions suppress trade while symmetric regions enable it. While the results are not uniform, they do provide support for the hypothesis (asymmetric regions trade less) while also providing additional support to the interactive relationship between global powers and regional powers.

\footnotetext{
${ }^{8}$ This would be a reason to exclude the measures of international concentration as well as the US CINC score. I include the variables for compatibility with the initial models; however, excluding these variables does not significantly alter the results. I include these models in the supplemental models of the appendix.
} 


\section{Discussion and Further Work}

The results from this research portray a consistent picture: regions of parity are more conducive to trade activity than regions of disparity. I offer two calculations of dominance here: disparity between the two strongest countries and regional dominance. Across most specifications, it is clear that disparity is a more consistent predictor of how regional power structures and hierarchy affect trade. In terms of systemic and major power theories about power and liberalization, this research indicates that such processes are not uniform. If we expect liberalization to increase and decrease with the rise and decline of a single world power, this research indicates that such parabolic rise and declines will be globally bumpy based on local power distributions.

One area that this research speaks to is the methodological use of regions. A significant finding of this study suggests that there is an interactive relationship between regions and the global political climate; fundamentally, the regional behavior and existence of states is not isolated from global trends and global trends interact differently with each regions. A natural step from this project is to continue to investigate the various conceptualizations of regions (e.g. Russett (1967) and Lemke (2002)) and how they interact with global pressures. Consequently, this also means that regions are not reliable microcosms for global theories of international relations. In the case of hierarchy, dominant regional powers do not replicate the behavior of global powers and pursue aggressive liberalization; instead, they react to such forces and attempt to free ride when they are capable of doing so. This stark difference suggests that some major power theories need additional context when applied to minor powers.

This research provides three different avenues to further explore these questions. First, hierarchy in the global system is not uniform in either spatial nor temporal terms. Even when there is one dominant state, let alone when there is a bipolar system, the extent of 
that state's reach is going to be dependent upon its relationship with states in every region. According to Lake (2009), the US manages its hierarchical relationships with contractual bargaining and the extent of its influence is dependent upon these contracts. Regions in which the United States is well-entrenched are going to have more pressure for economic and security processes than areas where the United States is less well entrenched. Temporally speaking, periods of hegemony are not uniform either as hegemonic periods include phases where dominant states may be ascending, stable, or declining-examining the relative degree of global hierarchy and emerging alternatives can bring nuance the results in this paper. Some arguments in the extant literature suggest effective dominant states can and will use their position to realign rivals' preferences through global norms and encouraging global liberalization (Tammen and Kugler 2006). The relationship between dominant powers and emerging powers is unlikely to uniformly affect regions as such transitions themselves are not linear nor uniform processes. Evaluating the conditioning effect of transition periods on regional configurations could prove to be a fruitful area of research as well as answer evolving questions about the trajectory of China relative to the United States.

Two additional research suggestions from the assumptions and empirical evidence include bringing in preferences and accounting for flexible hierarchy. The theoretical section of this paper assumes preferences to derive from regional power distributions. While this is not an unreasonable assumption to make in international relations scholarship, it is one that is testable. Typically, preferences are difficult to measure and, even when countries convey them publicly, it is unclear whether stated intentions are genuine or strategic misrepresentation. Recent scholarship has dug deeper into some metrics of preference revelation, such as state voting in the United Nations, to sort countries along ideological axes (Voeten 2013), or using alliance portfolios to judge foreign policy similarity (Signorino and Ritter 1999). Attempting to find the spatial-ideological difference between the United States and regional powers may reveal bumps in the bumps of liberalization — states aligned more with the United States may 
have less of a suppressing effect upon trade than states that do not align with the United States.

In both cases, there is a serious case of endogeneity: preferences and relationship with the United States is likely dependent, at least partially, upon the state's relations with other states in the region. Thus, disentangling the incentives derived from power versus those that come from other exogenous sources requires careful consideration. 


\section{References}

Allen, Michael A and Matthew DiGiuseppe. 2013. "Tightening the belt: Sovereign debt and alliance formation." International Studies Quarterly 57(4):647-659.

Alt, James E, Randall L Calvert and Brian D Humes. 1988. "Reputation and hegemonic stability: A game-theoretic analysis." American Political Science Review 82(2):445-466.

Anderson, James E. 1979. "A theoretical foundation for the gravity equation." American Economic Review 69(1):106-116.

Babayan, Nelli. 2015. "The return of the empire? Russia's counteraction to transatlantic democracy promotion in its near abroad." Democratization 22(3):438-458.

Bailey, Michael, Judith Goldstein and Barry R. Weingast. 1997. "The institutional roots of American trade: politics, coalitions, and international trade." World Politics 4(3):309-338.

Barbieri, Katherine. 1996. "Economic interdependence: A path to peace or a source of interstate conflict?" Journal of Peace Research 33(1):29-49.

Barbieri, Katherine, Omar MG Keshk and Brian M Pollins. 2009. "Trading data evaluating our assumptions and coding rules." Conflict Management and Peace Science 26(5):471491.

Bergstrand, Jeffrey H. 1985. "The gravity equation in international trade: some microeconomic foundations and empirical evidence." The review of economics and statistics $67(3): 474-481$.

Bhagwati, Jagdish N. and Arvind Panagariya. 1999. Preferential trading areas and multilateralism-strangers, friends, or foes. In Trading blocs: Alternative approaches to analyzing preferential Trade Agreements, ed. Jagdish N. Bhagwati, Pravin Krishna and Arvind Panagariya. Cambridge, MA: MIT Press pp. 33-100.

Brambor, Thomas, William Roberts Clark and Matt Golder. 2006. "Understanding interaction models: Improving empirical analyses." Political analysis 14(1):63-82.

Brander, J and B Spencer. 1992. Tariff protection and imperfect competition. In Imperfect competition and international trade, ed. Gene M. Grossman. Cambridge, MA: MIT pp. 107-119.

Bremer, Stuart A. 1992. "Dangerous dyads: conditions affecting the likelihood of interstate war, 1816-1965." The Journal of Conflict Resolution 36(2):309-341.

Carrere, Céline. 2006. "Revisiting the effects of regional trade agreements on trade flows with proper specification of the gravity model." European Economic Review 50(2):223-247. 
Chase-Dunn, Christopher, Yukio Kawano and Benjamin D Brewer. 2000. "Trade globalization since 1795: Waves of integration in the world-system." American Sociological Review $65(1): 77-95$.

Conybeare, John A. 1984. "Public goods, prisoners' dilemmas and the international political economy." International Studies Quarterly 28(1):5-22.

Dinan, Desmond. 2004. Europe recast: a history of European Union. Vol. 373 Boulder, CO: Lynne Rienner Publishers.

Frankel, Jeffrey A, David Romer et al. 1999. "Does trade cause growth?" American Economic Review 89(3):379-399.

Freinkman, Lev, Evgeny Polyakov and Caroline Revenco. 2004. "Trade performance and regional integration of the CIS countries." Available at SSRN 2401724.

Gallagher, J. and R. Robinson. 1953. "The imperialism of free trade." The Economic History Review 6(1):1-15.

Gillingham, John. 2004. Coal, steel, and the rebirth of Europe, 1945-1955: the Germans and French from Ruhr conflict to Economic Community. Cambridge, MA: Cambridge University Press.

Gilpin, Robert. 1983. War and change in world politics. Cambridge, UK: Cambridge University Press.

Gleditsch, Kristian Skrede and Michael D. Ward. 2008. Spatial regression models. Thousand Oaks, CA: Sage.

Gleditsch, K.S. 2002. "Expanded trade and GDP data." Journal of Conflict Resolution $46(5): 712$.

Gowa, Joanne. 1989. "Rational hegemons, excludable goods, and small groups: An epitaph for hegemonic stability theory?" World Politics 41(3):307-324.

Hirschman, Albert O. 1945. National power and the structure of foreign trade. Berkeley, CA: University of California Press.

Hiscox, Michael J. 1999. "The magic bullet? The RTAA, institutional reform, and trade liberalization." International Organization 54(4):669-698.

Isard, Walter. 1954. "Location theory and trade theory: short-run analysis." The Quarterly Journal of Economics 68(2):305-320.

Keohane, Robert O. 2005. After hegemony: Cooperation and discord in the world political economy. Princeton, NJ: Princeton University Press. 
Keshk, O.M.G., B.M. Pollins and R. Reuveny. 2004. "Trade still follows the flag: The primacy of politics in a simultaneous model of interdependence and armed conflict." Journal of Politics 66(4):1155-1179.

Kim, Hyng Min. 2010. "Comparing measures of national power." International Political Science Review 31(4):405-427.

Kindleberger, Charles P. 1973. The world in depression 1929-39. Revised and enlarged edition ed. Berkeley: University of California Press.

Krasner, Stephen D. 1976. "State power and the structure of international trade." World Politics 28(3):317-347.

Lake, David A. 2009. Hierarchy in International Relations. Ithaca, NY: Cornell University Press.

Lemke, Douglas. 2002. Regions of War and Peace. Cambridge, MA: Cambridge University Press.

Mansfield, Edward D. 1993. "Concentration, polarity, and the distribution of power." International Studies Quarterly 37(1):105-128.

Martínez-Zarzoso, Inmaculada and Felicitas Nowak-Lehmann. 2003. "Augmented gravity model: An empirical application to Mercosur-European Union trade flows." Journal of Applied Economics 6(2):291-316.

Midford, Paul. 1993. "International trade and domestic politics: improving on Rogowski's model of political alignments." International Organization 47(4):535-535.

Newnham, Randall E. 2015. "Georgia on my mind? Russian sanctions and the end of the Rose Revolution." Journal of Eurasian Studies 6(2):161-170.

Nygren, Bertil. 2007. The rebuilding of Greater Russia: Putin's foreign policy towards the CIS countries. Vol. 4 Routledge.

Organski, A.F.K. 1958. World Poltiics. New York: Alfred A Knopf.

Organski, A.F.K. and Jacek Kugler. 1980. The War Ledger. Chicago: University of Chicago Press.

Ray, James Lee and J David Singer. 1973. "Measuring the concentration of power in the international system." Sociological Methods \& Research 1(4):403-437.

Rose, Andrew. 2004. "Do we really know that the WTO increases trade?" American Economic Review 94(1):98-114. 
Ross, Stephen A. 1973. The economic theory of agency: The principal's problem. In The theory of the firm: Critical perspectives on business and management, ed. Nicolai J. Foss. New York, NY: Routledge pp. 81-88.

Russett, Bruce M. 1967. International regions and the international system. Greenwood Press.

Russett, Bruce M. and John R. Oneal. 2001. Triangulating peace: Democracy, interdependence, and international organizations. New York: Norton.

Sahr, Robert. 2003. "Inflation conversion factors for dollars 1665 to estimated 2015." Oregon State University . Accessed: 6/10/2015.

URL: $\quad$ http://liberalarts.oregonstate.edu/spp/polisci/faculty-staff/robert-sahr/inflationconversion-factors-years-1774-estimated-2024-dollars-recent-years/individual-yearconversion-factor-table-0

Sahr, Robert. 2004. "Using inflation-adjusted dollars in analyzing political developments." Political Science and Politics 37(2):273-284.

Sarkees, Meredith R. and Frank Wayman. 2010. Resort to war, 1816-200\%. Washington: CQ Press.

Scherrer, Christoph. 1995. "The commitment to a liberal world market order as a hegemonic practice." Journal of World-Systems Research 1(4).

Signorino, Curtis S and Jeffrey M Ritter. 1999. "Tau-b or not tau-b: measuring the similarity of foreign policy positions." International Studies Quarterly 43(1):115-144.

Singer, J. David and Melvin Small. 1972. The wages of war, 1816-1965: A statistical handbook. New York: John Wiley.

Singer, J. David, Stuart Bremer and John Stuckey. 1972. Capability distribution, uncertainty, and major power war, 1820-1965. In Peace, war, and numbers, ed. Bruce M. Russett. Beverly Hills, CA: Sage Publications pp. 19-48.

Snidal, Duncan. 1985. "The limits of hegemonic stability theory." International Organization $39(4): 579-614$

Tammen, Ronald L and Jacek Kugler. 2006. Power transition and China-US conflicts. In The Asia-Pacific: A region in transition, ed. Jim Rolfe. Cambridge University Press: New York pp. 33-53.

Tullock, Gordon. 1967. "The welfare costs of tariffs, monopolies, and theft." Economic Inquiry 5(3):224-232.

Voeten, Erik. 2013. Data and analyses of voting in the United Nations General Assembly. In Routledge handbook of international organization. Routledge pp. 54-66. 
Wallerstein, Immanuel M. 2000. The rise and future demise of the world capitalist system: Concepts for comparative analysis. In The essential Wallerstein, ed. Immanuel M. Wallerstein. New York: The New Press pp. 71-105.

Waltz, Kenneth N. 1979. Theory of international politics. New York, NY: McGraw Hill.

Yarbrough, Beth V and Robert M Yarbrough. 1987. "Institutions for the governance of opportunism in international trade." Journal of Economics \& Organization 3:129. 


\section{Global Hierarchy}

\section{Dominance Parity}

\section{Dominance}

\section{Regional Hierarchy}

\begin{tabular}{|c|c|c|}
\hline Parity & $\begin{array}{l}\text { Global Promotion } \\
\text { Regional Adoption }\end{array}$ & $\begin{array}{l}\text { Global Defection } \\
\text { Regional Adoption }\end{array}$ \\
\hline
\end{tabular}

Figure 1: Theoretical expectations about the interplay between global configurations and regional configurations and their relation to liberalization promotion.

(a)

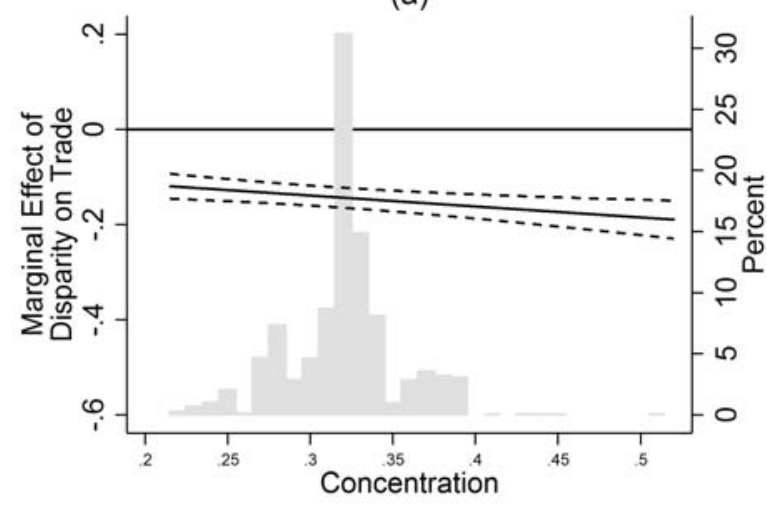

(c)

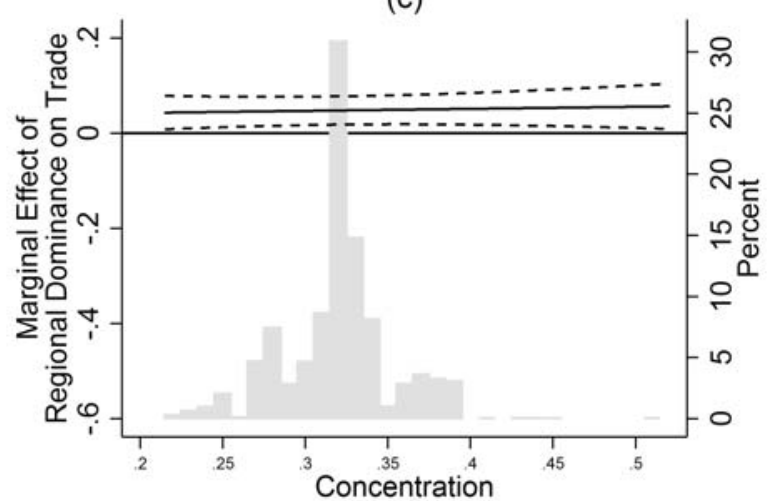

(b)

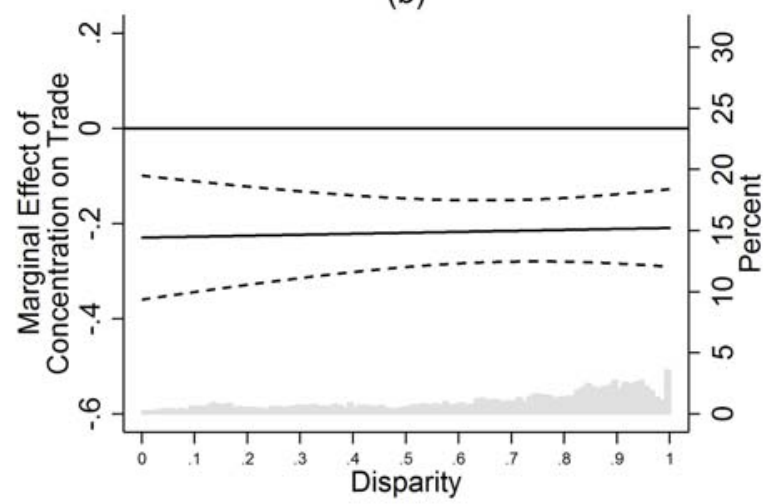

(d)

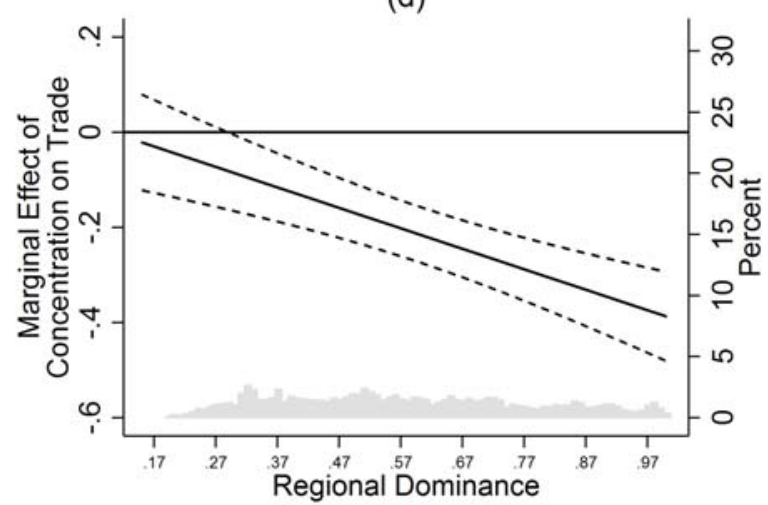

Figure 2: Marginal Effects of Concentration and Power across Table 1 
(a)

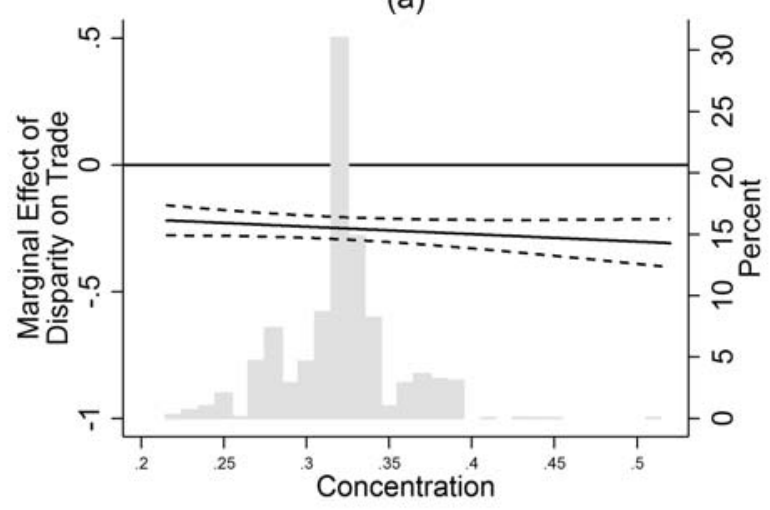

(c)

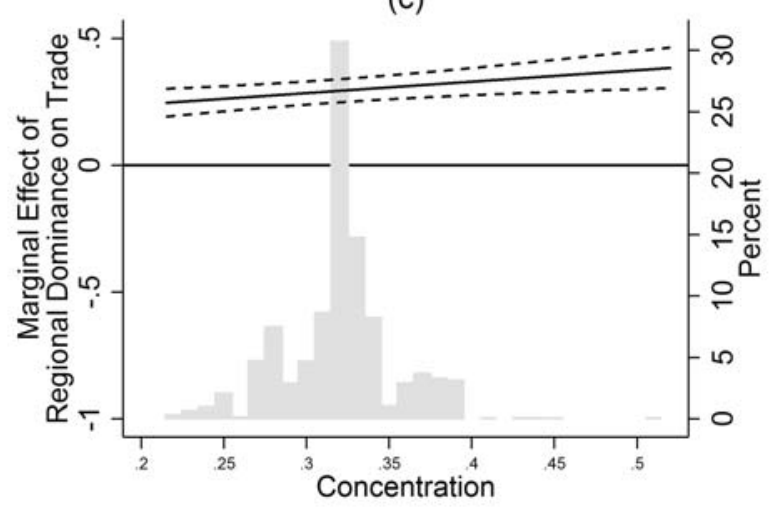

(b)

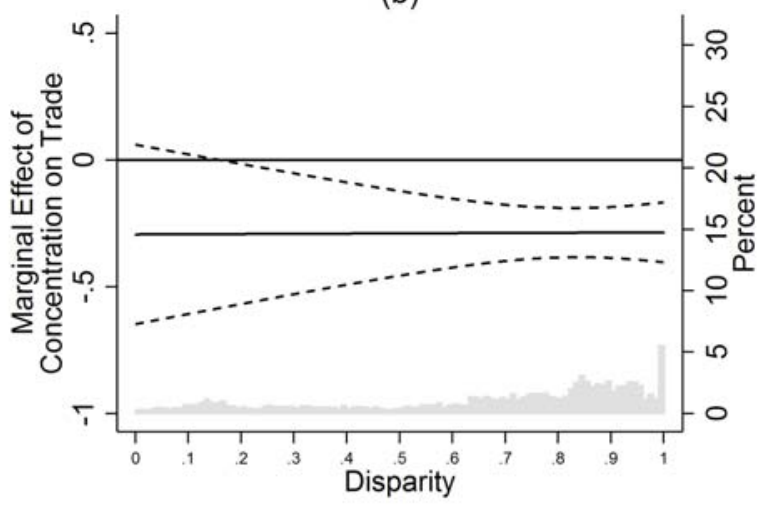

(d)

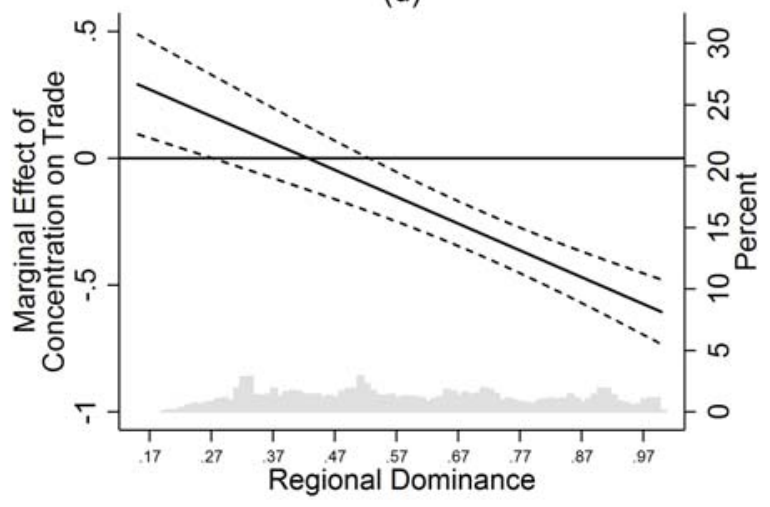

Figure 3: Marginal Effects of Concentration and Power across Table 2 
This is an author-produced, peer-reviewed version of this article. The final, definitive version of this document can be found online at the Journal of Conflict Resolution, published by SAGE. Copyright restrictions may apply. doi: 10.1177/0022002716669809

(a)

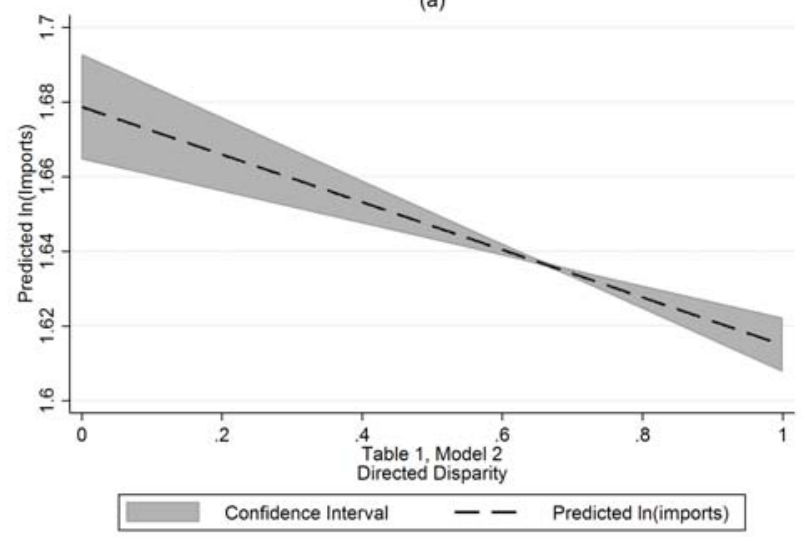

(c)

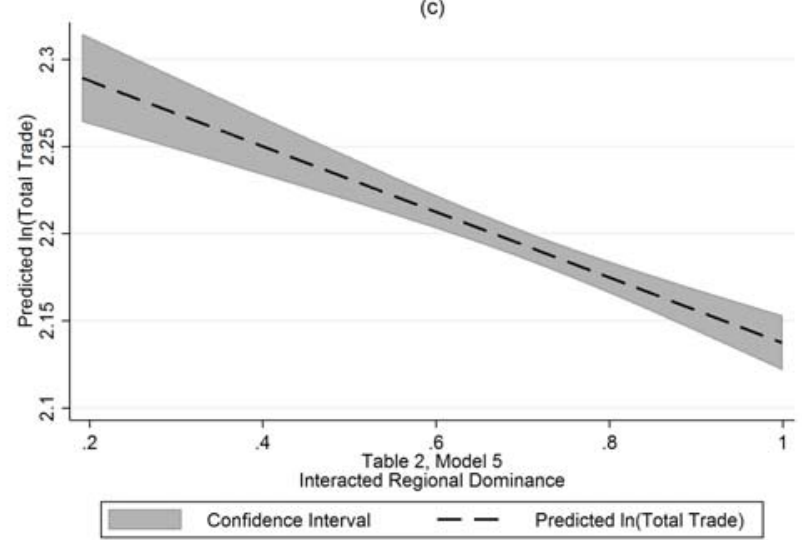

(b)

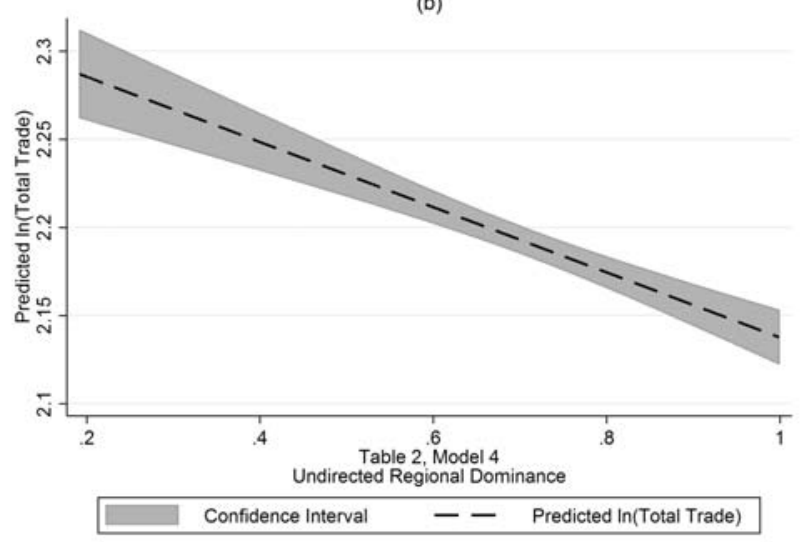

(d)

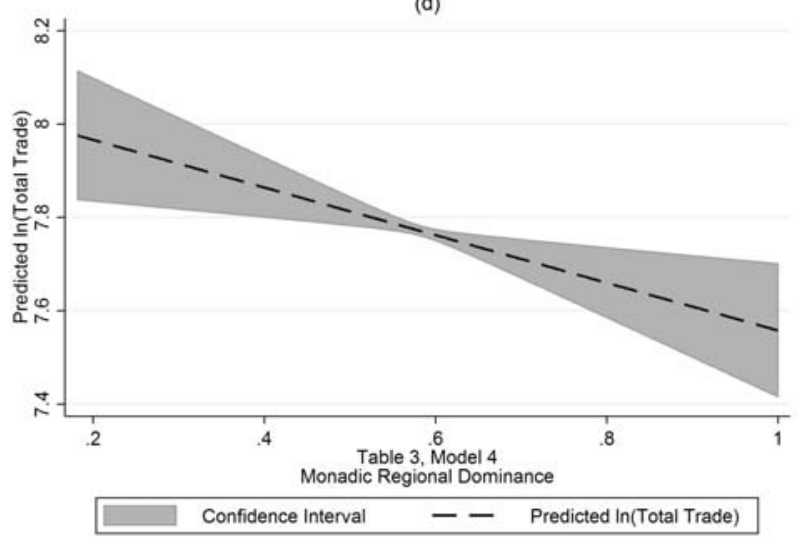

Figure 4: Predicted Level of Trade across Multiple Models 
Table 1: Predicting Imports using Correlates of War Trade Data for Directed Dyads, 18712007

\begin{tabular}{|c|c|c|c|c|c|}
\hline & $\begin{array}{c}(1) \\
\text { Imports } \mathrm{AB}\end{array}$ & $\begin{array}{c}(2) \\
\text { Imports } A B\end{array}$ & $\begin{array}{c}(3) \\
\text { Imports } \mathrm{AB}\end{array}$ & $\begin{array}{c}(4) \\
\text { Imports } \mathrm{AB}\end{array}$ & $\begin{array}{c}(5) \\
\text { Imports } A B\end{array}$ \\
\hline $\operatorname{Disparity}_{A}$ & & $\begin{array}{c}-0.0638^{* * *} \\
(0.0107)\end{array}$ & $\begin{array}{c}-0.0716^{* *} \\
(0.0280)\end{array}$ & & \\
\hline Disparity $_{B}$ & & $\begin{array}{c}-0.0666^{* * *} \\
(0.0115)\end{array}$ & $\begin{array}{c}-0.0666^{* * *} \\
(0.0115)\end{array}$ & & \\
\hline Disparity Interaction $_{A}$ & & & $\begin{array}{c}0.0247 \\
(0.0829)\end{array}$ & & \\
\hline Regional Dominance $_{A}$ & & & & $\begin{array}{c}-0.1030^{* * *} \\
(0.0152)\end{array}$ & $\begin{array}{c}0.0329 \\
(0.0332)\end{array}$ \\
\hline Regional Dominance $_{B}$ & & & & $\begin{array}{c}-0.1079^{* * *} \\
(0.0152)\end{array}$ & $\begin{array}{c}-0.1080^{* * *} \\
(0.0152)\end{array}$ \\
\hline Dominance Interaction $_{A}$ & & & & & $\begin{array}{c}-0.4267^{* * *} \\
(0.0930)\end{array}$ \\
\hline Concentration & $\begin{array}{c}-0.2029^{* * *} \\
(0.0285)\end{array}$ & $\begin{array}{c}-0.2191^{* * *} \\
(0.0332)\end{array}$ & $\begin{array}{c}-0.2352^{* * *} \\
(0.0665)\end{array}$ & $\begin{array}{c}-0.2077^{* * *} \\
(0.0299)\end{array}$ & $\begin{array}{c}0.0389 \\
(0.0632)\end{array}$ \\
\hline CINC $_{U S}$ & $\begin{array}{c}-0.7892^{* * *} \\
(0.0349)\end{array}$ & $\begin{array}{c}-0.9431^{* * *} \\
(0.0413)\end{array}$ & $\begin{array}{c}-0.9427^{* * *} \\
(0.0413)\end{array}$ & $\begin{array}{c}-0.8292^{* * *} \\
(0.0364)\end{array}$ & $\begin{array}{c}-0.8248^{* * *} \\
(0.0365)\end{array}$ \\
\hline $\mathrm{CINC}_{A}$ & $\begin{array}{c}1.7166^{* * *} \\
(0.1806)\end{array}$ & $\begin{array}{c}1.7739^{* * *} \\
(0.2015)\end{array}$ & $\begin{array}{c}1.7722^{* * *} \\
(0.2022)\end{array}$ & $\begin{array}{c}1.8047^{* * *} \\
(0.1848)\end{array}$ & $\begin{array}{l}1.8225^{* * *} \\
(0.1855)\end{array}$ \\
\hline $\mathrm{CINC}_{B}$ & $\begin{array}{c}1.8764^{* * *} \\
(0.1884)\end{array}$ & $\begin{array}{c}1.8903^{* * *} \\
(0.2161)\end{array}$ & $\begin{array}{c}1.8904^{* * *} \\
(0.2161)\end{array}$ & $\begin{array}{c}1.9620^{* * *} \\
(0.1928)\end{array}$ & $\begin{array}{c}1.9592^{* * *} \\
(0.1928)\end{array}$ \\
\hline $\ln (\mathrm{pop})_{A}$ & $\begin{array}{c}-0.0158^{* *} \\
(0.0062)\end{array}$ & $\begin{array}{l}-0.0133^{*} \\
(0.0069)\end{array}$ & $\begin{array}{l}-0.0133^{*} \\
(0.0069)\end{array}$ & $\begin{array}{c}-0.0192^{* * *} \\
(0.0064)\end{array}$ & $\begin{array}{c}-0.0189^{* * *} \\
(0.0064)\end{array}$ \\
\hline $\ln (\mathrm{pop})_{B}$ & $\begin{array}{c}-0.0634^{* * *} \\
(0.0065)\end{array}$ & $\begin{array}{c}-0.0626^{* * *} \\
(0.0073)\end{array}$ & $\begin{array}{c}-0.0626^{* * *} \\
(0.0073)\end{array}$ & $\begin{array}{c}-0.0667^{* * *} \\
(0.0067)\end{array}$ & $\begin{array}{c}-0.0668^{* * *} \\
(0.0067)\end{array}$ \\
\hline War & $\begin{array}{c}-0.0786^{* * *} \\
(0.0030)\end{array}$ & $\begin{array}{c}-0.0854^{* * *} \\
(0.0033)\end{array}$ & $\begin{array}{c}-0.0854^{* * *} \\
(0.0033)\end{array}$ & $\begin{array}{c}-0.0784^{* * *} \\
(0.0031)\end{array}$ & $\begin{array}{c}-0.0781^{* * *} \\
(0.0031)\end{array}$ \\
\hline $\ln$ (Imports) & $\begin{array}{c}0.7810^{* * *} \\
(0.0021)\end{array}$ & $\begin{array}{c}0.7775^{* * *} \\
(0.0024)\end{array}$ & $\begin{array}{c}0.7775^{* * *} \\
(0.0024)\end{array}$ & $\begin{array}{c}0.7781^{* * *} \\
(0.0022)\end{array}$ & $\begin{array}{c}0.7781^{* * *} \\
(0.0022)\end{array}$ \\
\hline Constant & $\begin{array}{c}-17.6640^{* * *} \\
(0.4318)\end{array}$ & $\begin{array}{c}-17.6173^{* * *} \\
(0.4763)\end{array}$ & $\begin{array}{c}-17.6155^{* * *} \\
(0.4767)\end{array}$ & $\begin{array}{c}-17.3307^{* * *} \\
(0.4403)\end{array}$ & $\begin{array}{c}-17.3869^{* * *} \\
(0.4422)\end{array}$ \\
\hline$R^{2}$ & 0.708 & 0.701 & 0.701 & 0.704 & 0.704 \\
\hline Observations & 1027605 & 826422 & 826422 & 976455 & 976455 \\
\hline
\end{tabular}

${ }^{*} \mathrm{p} \leq 0.10 ;{ }^{* *} \mathrm{p} \leq 0.05 ;{ }^{* * *} \mathrm{p} \leq 0.01$

Each model employs clustered standard errors for the directed-dyad. 
Table 2: Predicting Total Trade using Correlates of War Trade Data for Undirected Dyads, 1871-2007

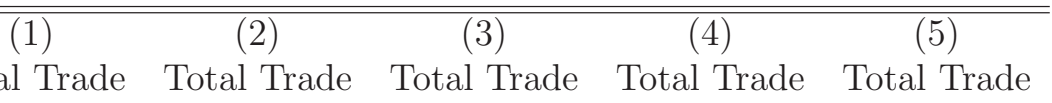

\begin{tabular}{|c|c|c|c|c|c|}
\hline Disparity $_{\max }$ & & $\begin{array}{c}-0.1529^{* * *} \\
(0.0223)\end{array}$ & $\begin{array}{c}-0.1576^{* *} \\
(0.0691)\end{array}$ & & \\
\hline Disparity Interaction $_{\max }$ & & & $\begin{array}{c}0.0150 \\
(0.2086)\end{array}$ & & \\
\hline Regional Dominance $_{\max }$ & & & & $\begin{array}{c}-0.1850^{* * *} \\
(0.0232)\end{array}$ & $\begin{array}{c}0.1478^{* * *} \\
(0.0556)\end{array}$ \\
\hline Dominance Interaction $_{\max }$ & & & & & $\begin{array}{c}-1.0531^{* * *} \\
(0.1616)\end{array}$ \\
\hline Concentration & $\begin{array}{c}-0.2709^{* * *} \\
(0.0426)\end{array}$ & $\begin{array}{c}-0.2904^{* * *} \\
(0.0496)\end{array}$ & $\begin{array}{c}-0.3025^{*} \\
(0.1807)\end{array}$ & $\begin{array}{c}-0.2828^{* * *} \\
(0.0448)\end{array}$ & $\begin{array}{c}0.4451^{* * *} \\
(0.1228)\end{array}$ \\
\hline $\mathrm{CINC}_{U S}$ & $\begin{array}{c}-1.1035^{* * *} \\
(0.0500)\end{array}$ & $\begin{array}{c}-1.2407^{* * *} \\
(0.0584)\end{array}$ & $\begin{array}{c}-1.2405^{* * *} \\
(0.0582)\end{array}$ & $\begin{array}{c}-1.1603^{* * *} \\
(0.0521)\end{array}$ & $\begin{array}{c}-1.1559^{* * *} \\
(0.0521)\end{array}$ \\
\hline $\mathrm{CINC}_{\max }$ & $\begin{array}{c}1.7682^{* * *} \\
(0.1941)\end{array}$ & $\begin{array}{c}1.8156^{* * *} \\
(0.2166)\end{array}$ & $\begin{array}{c}1.8153^{* * *} \\
(0.2171)\end{array}$ & $\begin{array}{c}1.8646^{* * *} \\
(0.2002)\end{array}$ & $\begin{array}{c}1.8861^{* * *} \\
(0.2010)\end{array}$ \\
\hline $\ln (\mathrm{Pop})_{\text {sum }}$ & $\begin{array}{c}-0.0193^{* * *} \\
(0.0064)\end{array}$ & $\begin{array}{c}-0.0154^{* *} \\
(0.0069)\end{array}$ & $\begin{array}{c}-0.0154^{* *} \\
(0.0069)\end{array}$ & $\begin{array}{c}-0.0211^{* * *} \\
(0.0066)\end{array}$ & $\begin{array}{c}-0.0206^{* * *} \\
(0.0066)\end{array}$ \\
\hline War & $\begin{array}{c}-0.0929^{* * *} \\
(0.0045)\end{array}$ & $\begin{array}{c}-0.1011^{* * *} \\
(0.0050)\end{array}$ & $\begin{array}{c}-0.1011^{* * *} \\
(0.0050)\end{array}$ & $\begin{array}{c}-0.0937^{* * *} \\
(0.0046)\end{array}$ & $\begin{array}{c}-0.0931^{* * *} \\
(0.0046)\end{array}$ \\
\hline $\ln$ (Total trade) & $\begin{array}{c}0.7793^{* * *} \\
(0.0028)\end{array}$ & $\begin{array}{c}0.7776^{* * *} \\
(0.0032)\end{array}$ & $\begin{array}{c}0.7776^{* * *} \\
(0.0032)\end{array}$ & $\begin{array}{c}0.7763^{* * *} \\
(0.0029)\end{array}$ & $\begin{array}{c}0.7763^{* * *} \\
(0.0029)\end{array}$ \\
\hline Constant & $\begin{array}{c}-16.5579^{* * *} \\
(0.5880)\end{array}$ & $\begin{array}{c}-16.3245^{* * *} \\
(0.6498)\end{array}$ & $\begin{array}{c}-16.3225^{* * *} \\
(0.6544)\end{array}$ & $\begin{array}{c}-16.2818^{* * *} \\
(0.6006)\end{array}$ & $\begin{array}{c}-16.4445^{* * * *} \\
(0.6074)\end{array}$ \\
\hline$R^{2}$ & 0.723 & 0.718 & 0.718 & 0.720 & 0.720 \\
\hline Observations & 490646 & 395665 & 395665 & 466019 & 466019 \\
\hline
\end{tabular}

${ }^{*} \mathrm{p} \leq 0.10 ;{ }^{* *} \mathrm{p} \leq 0.05 ;{ }^{* * *} \mathrm{p} \leq 0.01$

Each model employs clustered standard errors for the undirected-dyad. 
Table 3: Predicting Monadic Trade Activity, 1871-2007

\begin{tabular}{|c|c|c|c|c|}
\hline & $\begin{array}{c}(1) \\
\text { Imports COW }\end{array}$ & $\begin{array}{c}(2) \\
\text { Imports COW }\end{array}$ & $\begin{array}{c}(3) \\
\text { Total Trade }\end{array}$ & $\begin{array}{c}(4) \\
\text { Total Trade }\end{array}$ \\
\hline Disparity & $\begin{array}{c}-0.2259^{* *} \\
(0.1123)\end{array}$ & & $\begin{array}{c}-0.2497^{* *} \\
(0.1192)\end{array}$ & \\
\hline Regional Dominance & & $\begin{array}{c}-0.4992^{* * *} \\
(0.1671)\end{array}$ & & $\begin{array}{c}-0.5107^{* * *} \\
(0.1730)\end{array}$ \\
\hline Concentration & $\begin{array}{c}4.1850^{* * *} \\
(0.3753)\end{array}$ & $\begin{array}{l}4.2288^{* * *} \\
(0.3777)\end{array}$ & $\begin{array}{c}4.5841^{* * *} \\
(0.4021)\end{array}$ & $\begin{array}{l}4.6255^{* * *} \\
(0.4049)\end{array}$ \\
\hline $\mathrm{CINC}_{U S}$ & $\begin{array}{c}-1.4767^{* * *} \\
(0.5068)\end{array}$ & $\begin{array}{c}-1.5152^{* * * *} \\
(0.5043)\end{array}$ & $\begin{array}{c}-1.1681^{* *} \\
(0.5255)\end{array}$ & $\begin{array}{c}-1.2015^{* *} \\
(0.5216)\end{array}$ \\
\hline $\ln ($ Pop $)$ & $\begin{array}{c}0.1720^{* * *} \\
(0.0454)\end{array}$ & $\begin{array}{c}0.1467^{* * *} \\
(0.0477)\end{array}$ & $\begin{array}{c}0.1784^{* * *} \\
(0.0459)\end{array}$ & $\begin{array}{c}0.1522^{* * *} \\
(0.0489)\end{array}$ \\
\hline War & $\begin{array}{c}-0.4115^{* * *} \\
(0.0923)\end{array}$ & $\begin{array}{c}-0.4094^{* * *} \\
(0.0929)\end{array}$ & $\begin{array}{c}-0.4277^{* * *} \\
(0.0976)\end{array}$ & $\begin{array}{c}-0.4252^{* * *} \\
(0.0983)\end{array}$ \\
\hline $\mathrm{CINC}_{A}$ & $\begin{array}{c}0.1574 \\
(1.3305)\end{array}$ & $\begin{array}{c}0.3373 \\
(1.3035)\end{array}$ & $\begin{array}{l}-0.1459 \\
(1.4379)\end{array}$ & $\begin{array}{c}0.0273 \\
(1.4025)\end{array}$ \\
\hline $\ln$ (Imports) & $\begin{array}{c}0.7724^{* * *} \\
(0.0120)\end{array}$ & $\begin{array}{c}0.7708^{* * *} \\
(0.0118)\end{array}$ & & \\
\hline $\ln$ (Total trade) & & & $\begin{array}{c}0.7866^{* * *} \\
(0.0114)\end{array}$ & $\begin{array}{c}0.7853^{* * *} \\
(0.0112)\end{array}$ \\
\hline Constant & $\begin{array}{l}8.7086^{* *} \\
(4.0371)\end{array}$ & $\begin{array}{l}7.9713^{* *} \\
(3.9480)\end{array}$ & $\begin{array}{c}13.6235^{* * *} \\
(3.9186)\end{array}$ & $\begin{array}{c}12.8714^{* * *} \\
(3.8314)\end{array}$ \\
\hline$R^{2}$ & 0.800 & 0.800 & 0.800 & 0.800 \\
\hline Observations & 10515 & 10515 & 10515 & 10515 \\
\hline
\end{tabular}

${ }^{*} \mathrm{p} \leq 0.10 ;{ }^{* *} \mathrm{p} \leq 0.05 ;{ }^{* * *} \mathrm{p} \leq 0.01$

Each model employs clustered standard errors for each country. 
This is an author-produced, peer-reviewed version of this article. The final, definitive version of this document can be found online at the Journal of Conflict Resolution, published by SAGE. Copyright restrictions may apply. doi: 10.1177/0022002716669809

Table 4: Predicting Imports using Correlates of War Trade Data for Dyriected Dyads by Hegemonic Period

\begin{tabular}{|c|c|c|c|c|c|c|}
\hline & $\begin{array}{c}(1) \\
\text { Pre-1914 }\end{array}$ & $\begin{array}{c}(2) \\
\text { Pre-1914 }\end{array}$ & $\begin{array}{c}(3) \\
\text { Inter-war }\end{array}$ & $\begin{array}{c}(4) \\
\text { Inter-war }\end{array}$ & $\begin{array}{c}(5) \\
\text { Post-WWII }\end{array}$ & $\begin{array}{c}(6) \\
\text { Post-WWII }\end{array}$ \\
\hline $\operatorname{Disparity}_{A}$ & $\begin{array}{l}-0.1049 \\
(0.1766)\end{array}$ & & $\begin{array}{c}-0.2493^{* * *} \\
(0.0796)\end{array}$ & & $\begin{array}{c}-0.0485^{* * *} \\
(0.0113)\end{array}$ & \\
\hline Disparity $_{B}$ & $\begin{array}{l}-0.0823 \\
(0.1713)\end{array}$ & & $\begin{array}{c}0.1181 \\
(0.0737)\end{array}$ & & $\begin{array}{c}-0.0707^{* * *} \\
(0.0121)\end{array}$ & \\
\hline Regional Dominance $_{A}$ & & $\begin{array}{l}-0.0951 \\
(0.3439)\end{array}$ & & $\begin{array}{c}-0.4929^{* * *} \\
(0.1177)\end{array}$ & & $\begin{array}{c}-0.0413^{* *} \\
(0.0171)\end{array}$ \\
\hline Regional Dominance $_{B}$ & & $\begin{array}{l}-0.0917 \\
(0.3851)\end{array}$ & & $\begin{array}{c}0.3953^{* * *} \\
(0.1213)\end{array}$ & & $\begin{array}{c}-0.0663^{* * *} \\
(0.0169)\end{array}$ \\
\hline $\mathrm{CINC}_{A}$ & $\begin{array}{c}5.7406^{* * *} \\
(1.3155)\end{array}$ & $\begin{array}{c}5.8263^{* * *} \\
(1.3861)\end{array}$ & $\begin{array}{c}2.0096^{* * *} \\
(0.6305)\end{array}$ & $\begin{array}{c}2.1208^{* * *} \\
(0.6329)\end{array}$ & $\begin{array}{c}2.8315^{* * *} \\
(0.3557)\end{array}$ & $\begin{array}{c}2.9312^{* * *} \\
(0.3520)\end{array}$ \\
\hline $\mathrm{CINC}_{B}$ & $\begin{array}{c}2.1974^{* * *} \\
(0.7711)\end{array}$ & $\begin{array}{c}2.1326^{* * *} \\
(0.7700)\end{array}$ & $\begin{array}{c}1.3891^{* * *} \\
(0.4921)\end{array}$ & $\begin{array}{c}1.2968^{* * *} \\
(0.4934)\end{array}$ & $\begin{array}{c}1.9428^{* * *} \\
(0.2810)\end{array}$ & $\begin{array}{c}1.9926^{* * *} \\
(0.2800)\end{array}$ \\
\hline $\ln (\mathrm{pop})_{A}$ & $\begin{array}{l}0.3479^{* *} \\
(0.1503)\end{array}$ & $\begin{array}{l}0.3550^{* *} \\
(0.1487)\end{array}$ & $\begin{array}{c}-0.9720^{* * *} \\
(0.2359)\end{array}$ & $\begin{array}{c}-1.0402^{* * *} \\
(0.2374)\end{array}$ & $\begin{array}{c}-0.0222^{* * *} \\
(0.0074)\end{array}$ & $\begin{array}{c}-0.0198^{* * *} \\
(0.0075)\end{array}$ \\
\hline $\ln (\mathrm{pop})_{B}$ & $\begin{array}{c}0.4673^{* * *} \\
(0.1806)\end{array}$ & $\begin{array}{c}0.4792^{* * *} \\
(0.1812)\end{array}$ & $\begin{array}{c}0.0155 \\
(0.1969)\end{array}$ & $\begin{array}{c}0.0803 \\
(0.2005)\end{array}$ & $\begin{array}{c}-0.0729^{* * *} \\
(0.0078)\end{array}$ & $\begin{array}{c}-0.0682^{* * *} \\
(0.0079)\end{array}$ \\
\hline War & $\begin{array}{c}-0.0557^{* *} \\
(0.0269)\end{array}$ & $\begin{array}{c}-0.0548^{* *} \\
(0.0274)\end{array}$ & $\begin{array}{c}-0.0722^{* * *} \\
(0.0236)\end{array}$ & $\begin{array}{c}-0.0698^{* * *} \\
(0.0232)\end{array}$ & $\begin{array}{c}-0.0895^{* * *} \\
(0.0035)\end{array}$ & $\begin{array}{c}-0.0891^{* * *} \\
(0.0035)\end{array}$ \\
\hline Concentration & $\begin{array}{c}2.9247^{* * *} \\
(0.9879)\end{array}$ & $\begin{array}{c}2.9273^{* * *} \\
(1.0018)\end{array}$ & $\begin{array}{l}-0.8514^{*} \\
(0.4561)\end{array}$ & $\begin{array}{l}-0.8536^{*} \\
(0.4548)\end{array}$ & $\begin{array}{c}-0.7233^{* * *} \\
(0.0393)\end{array}$ & $\begin{array}{c}-0.6970^{* * *} \\
(0.0394)\end{array}$ \\
\hline $\mathrm{CINC}_{U S}$ & $\begin{array}{c}2.7180^{* * *} \\
(0.7571)\end{array}$ & $\begin{array}{c}2.7183^{* * *} \\
(0.7704)\end{array}$ & $\begin{array}{l}-0.2665 \\
(0.6111)\end{array}$ & $\begin{array}{l}-0.1918 \\
(0.6092)\end{array}$ & $\begin{array}{c}0.5861^{* * *} \\
(0.0766)\end{array}$ & $\begin{array}{c}0.5652^{* * *} \\
(0.0767)\end{array}$ \\
\hline $\ln$ (Imports) & $\begin{array}{c}0.3821^{* * *} \\
(0.0336)\end{array}$ & $\begin{array}{c}0.3820^{* * *} \\
(0.0336)\end{array}$ & $\begin{array}{c}0.4916^{* * *} \\
(0.0119)\end{array}$ & $\begin{array}{c}0.4911^{* * *} \\
(0.0119)\end{array}$ & $\begin{array}{c}0.7700^{* * *} \\
(0.0024)\end{array}$ & $\begin{array}{c}0.7703^{* * *} \\
(0.0024)\end{array}$ \\
\hline Constant & $\begin{array}{c}-27.8658^{* * *} \\
(10.1245)\end{array}$ & $\begin{array}{c}-28.1502^{* * *} \\
(10.0674)\end{array}$ & $\begin{array}{c}-112.6089^{* * *} \\
(21.6200)\end{array}$ & $\begin{array}{c}-113.0690^{* * *} \\
(21.4949)\end{array}$ & $\begin{array}{c}-38.0410^{* * *} \\
(1.2317)\end{array}$ & $\begin{array}{c}-37.1685^{* * *} \\
(1.2430)\end{array}$ \\
\hline$R^{2}$ & 0.344 & 0.344 & 0.325 & 0.326 & 0.669 & 0.669 \\
\hline Observations & 9545 & 9545 & 16545 & 16545 & 792162 & 792162 \\
\hline
\end{tabular}

${ }^{*} \mathrm{p} \leq 0.10{ }^{* *} \mathrm{p} \leq 0.05 ;{ }^{* * *} \mathrm{p} \leq 0.01$

Each model employs clustered standard errors for the directed-dyad. 